Corrigendum

\title{
Corrigendum to "Sensitization of Cancer Cells through Reduction of Total Akt and Downregulation of Salinomycin-Induced pAkt, pGSk3 $\beta$, pTSC2, and p4EBP1 by Cotreatment with MK-2206”
}

\author{
Ae-Ran Choi, Ju-Hwa Kim, and Sungpil Yoon \\ Research Institute, National Cancer Center, Goyang-si, Gyeonggi-do 411-764, Republic of Korea \\ Correspondence should be addressed to Sungpil Yoon; yoons@ncc.re.kr \\ Received 9 August 2015; Accepted 28 September 2015 \\ Copyright ( 2015 Ae-Ran Choi et al. This is an open access article distributed under the Creative Commons Attribution License, \\ which permits unrestricted use, distribution, and reproduction in any medium, provided the original work is properly cited.
}

In the paper titled "Sensitization of Cancer Cells through Reduction of Total Akt and Downregulation of SalinomycinInduced pAkt, pGSk3 $\beta$, pTSC2, and p4EBP1 by Cotreatment with MK-2206" [1], in the Acknowledgment the funding number "NCC1310120" is wrong and it should be corrected as "NCC1310210."

\section{References}

[1] A.-R. Choi, J.-H. Kim, and S. Yoon, "Sensitization of cancer cells through reduction of total Akt and downregulation of salinomycin-induced pAkt, pGSk3 $\beta$, pTSC2, and p4EBP1 by cotreatment with MK-2206," BioMed Research International, vol. 2014, Article ID 295760, 8 pages, 2014. 

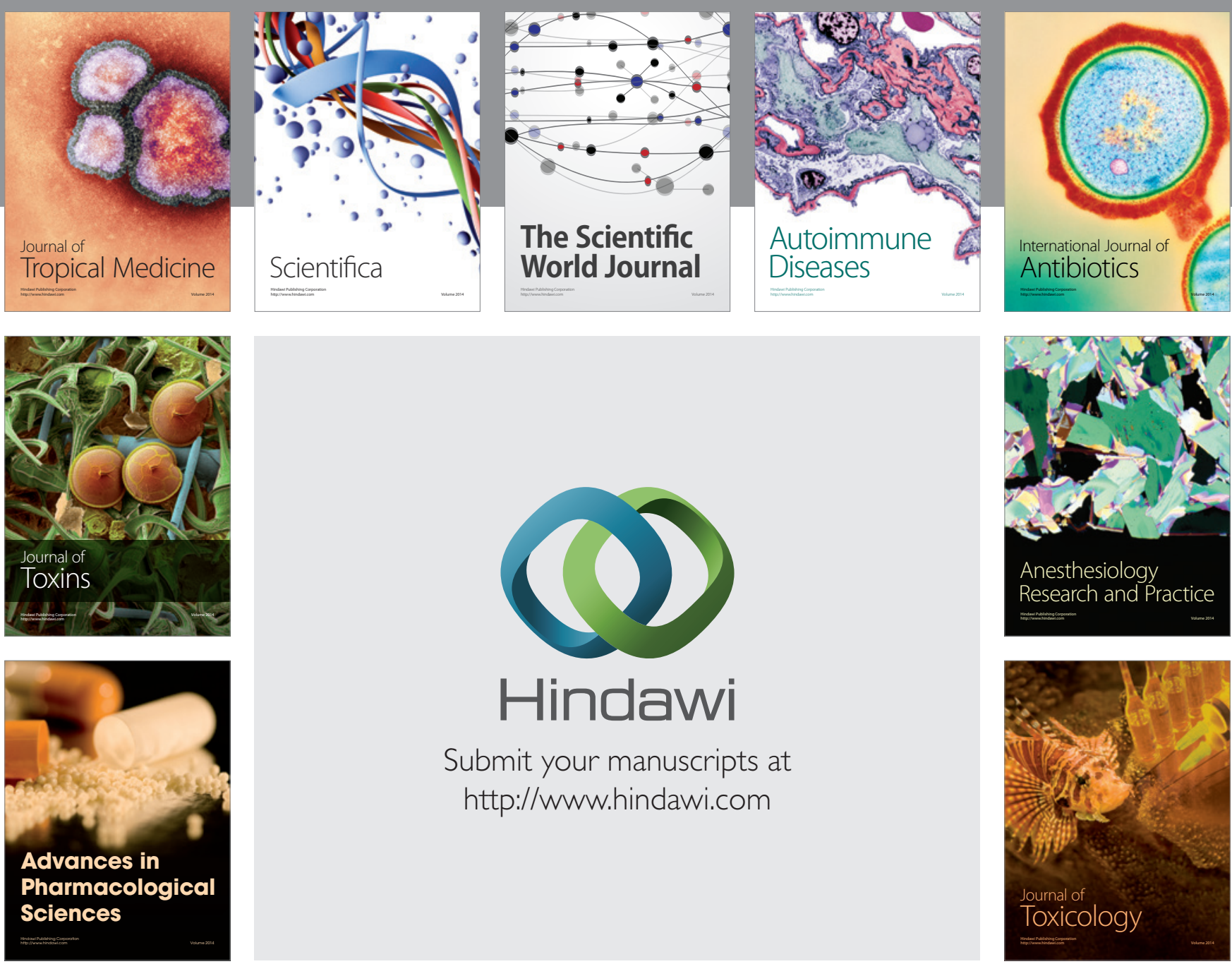

\section{Hindawi}

Submit your manuscripts at

http://www.hindawi.com
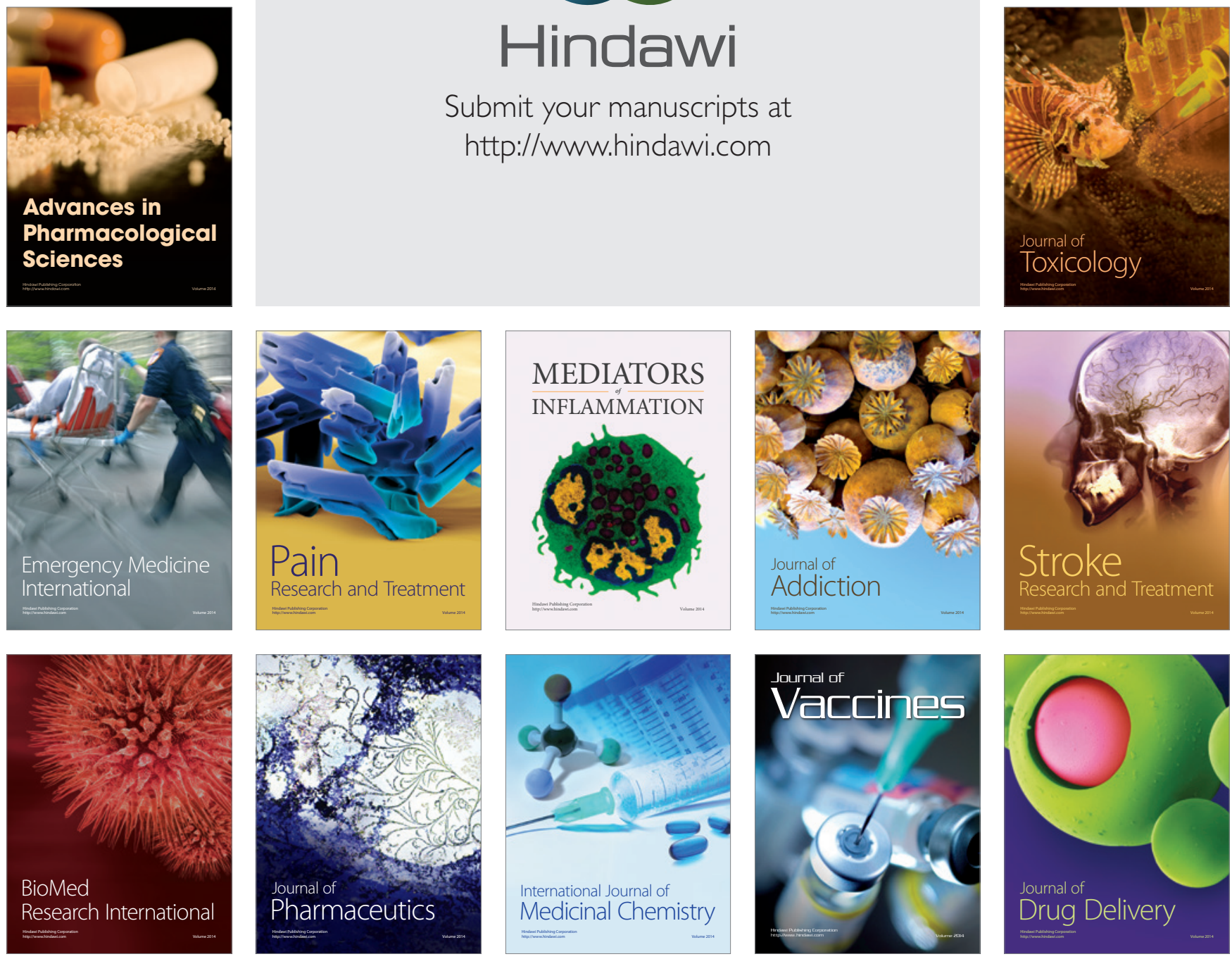